\title{
Leukaemia in flounder Platichthys flesus luscus from the Adriatic Sea: a case report
}

\author{
A. D. Vethaak ${ }^{1}$, P. W. Wester ${ }^{2}$ \\ 1 Ministry of Transport and Public Works, Public Works Department, Tidal Waters Division, c/o RIVO, PO Box 68, 1970 AB, \\ Ijmuiden, The Netherlands \\ ${ }^{2}$ Laboratory for Pathology, National Institute of Public Health and Environmental Protection, PO Box 1, 3720 BA, Bilthoven, The Netherlands
}

ABSTRACT: A unique case of leukaemia in flounder Platichthys flesus luscus, discovered incidentally during a survey from the Adriatic Sea, is presented. Several internal organs were affected by lymphoid tumour tissue.

Tumours of the lymphoid system have been reported in several freshwater fish, especially in populations of Esox species (pike) where they can reach epizootic proportions (Mulcahy 1980, Peters 1984). According to the literature there are, to date, few evidential cases of such conditions in marine fish. There are some examples of incidental cases of lymphoma in marine wild fish, but they all date from the first half of this century, and often have a questionable diagnosis. These (possible) cases concern 2 flounder species, Platichthys flesus and Psetta maetica, turbot Scophtalmus maximus, conger eel Conger conger, herring Clupea harengus, and cod Gadus morhua, as reported by Schlumberger \& Lucké (1965), Wellings (1969) and Harshbarger (1989). Two other, more recent, case reports refer to a specimen of channel catfish Ictalurus punctatus (Bowser et al. 1985) and turbot S. maximus (Ferguson \& Roberts 1975), both from commercial farms.

This paper presents a case of a lymphoid neoplasm in flounder Platichthys flesus luscus. The fish was collected during a preliminary survey of the occurrence of diseases in the Lagoon of Venice (Italian North Adriatic Sea), an area well known for its chemical pollution and eutrophication problems (e.g. Donazzolo et al. 1983, Sfriso et al. 1987). Although a link with local pollution cannot be established in this specimen, the case is of interest as it describes a rare finding of leukaemia, and the presence and relevance of this condition should be borne in mind for future studies.
Case description. This neoplastic condition was discovered incidentally in a female fish (2 yr old, $25 \mathrm{~cm}$ in length) during routine histological examinations of flounder, caught by a beam trawl net on the fishing grounds near the village of Ghiocca, Italy, in December 1988. From the catch, 100 fish, 2 to 3 yr of age, and in apparently good physical condition, were subjected to a gross pathological examination, which revealed no major abnormalities. At random 15 of these were then selected for histological examination of their liver, spleen and gut. Tissue samples were fixed in $10 \%$ formalin and routinely prepared for paraplast embedding. Sections $(5 \mu \mathrm{m})$ were cut and stained with haematoxylin and eosin ( $\mathrm{H} \& \mathrm{E}$ ). From the case reported, tissues were also embedded in glycolmethacorylate and sections $(1 \mu \mathrm{m})$ were stained with $\mathrm{H} \& \mathrm{E}$ and Giemsa for detailed microscopy.

Liver, spleen and gut of 1 female demonstrated varying grades of infiltration by lymphoid cells, clearly recognizable between the highly vacuolated hepatocytes (Figs. 1 and 2). Also, lymphatics around the pancreatic lobules and blood vessels contained such cells in their lumen. The spleen was mainly occupied by lymphoid tissue, between which trabeculae and vascular branches could be recognized.

The distribution of lymphoid cells in the gut showed a characteristic pattern: besides heavy infiltration of the propria mucosae, a distinct layer of lymphoid cells could also be found at the basis of the columnar epithelial cells, with occasional focal expansion in the epithelial layer (Figs. 3 and 4).

Under high magnification (Fig. 2) the implied cells exhibited characteristics of lymphoid cells, indicating a 


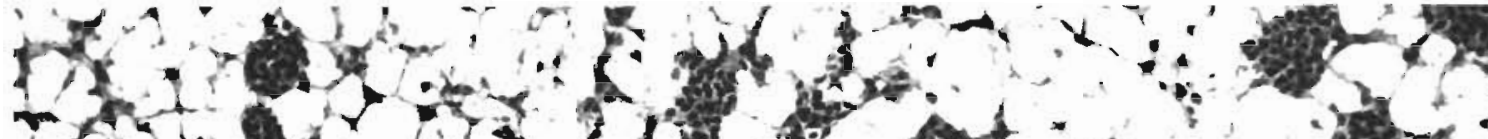

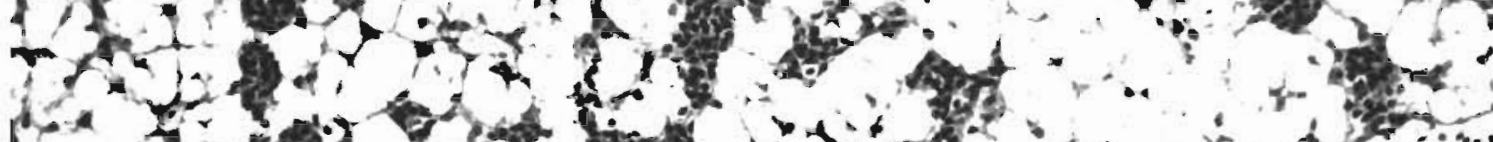

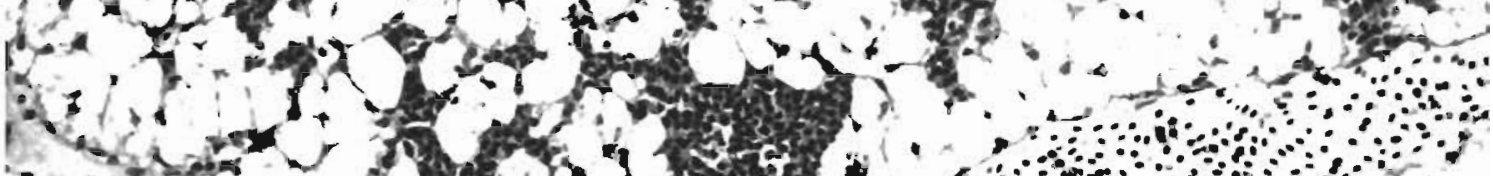

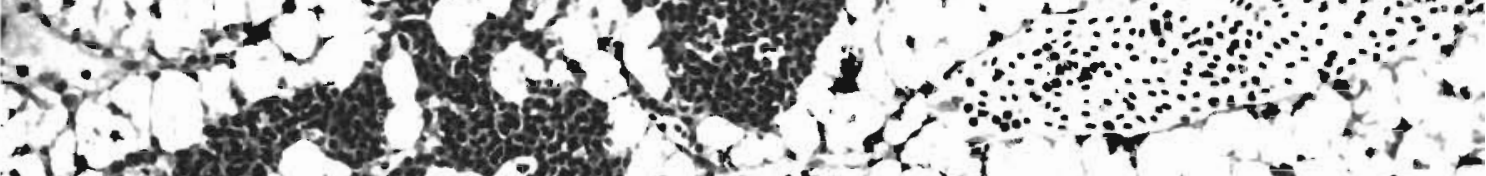

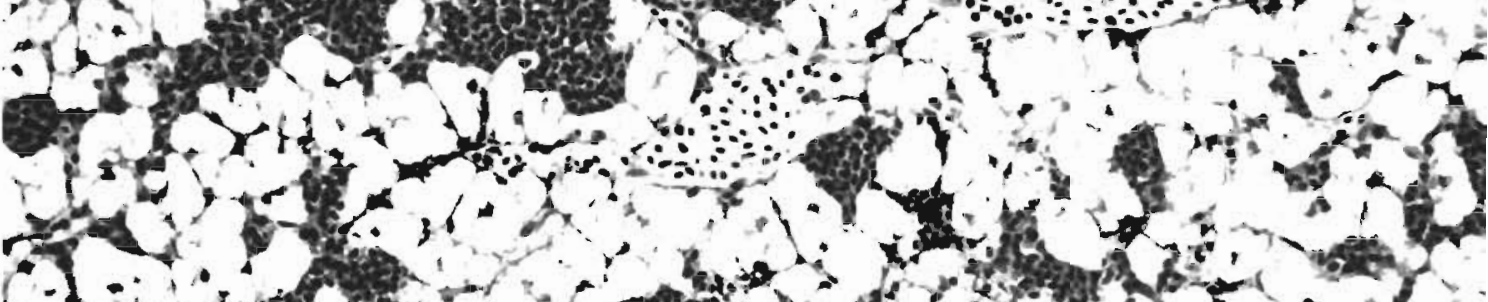

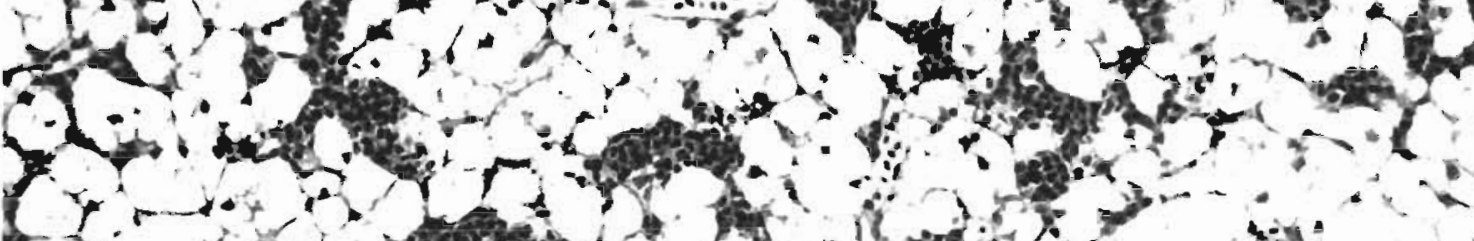
$(x+2)+20+2$

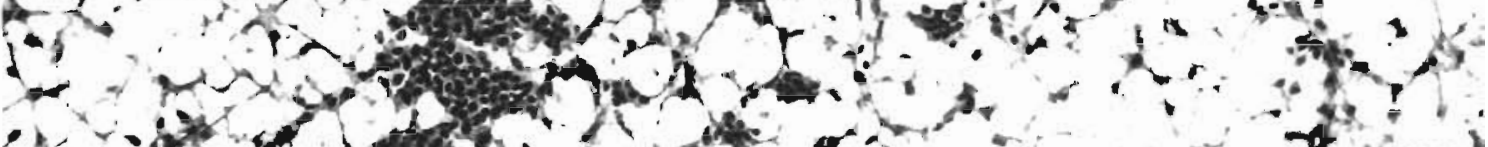

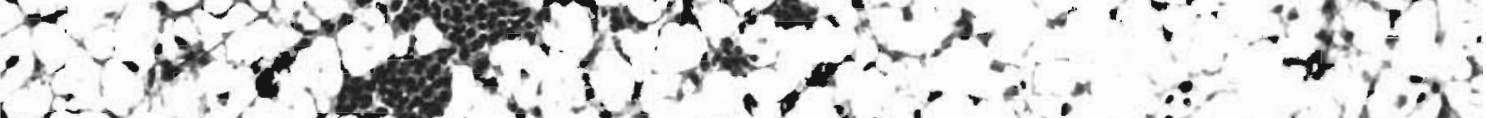

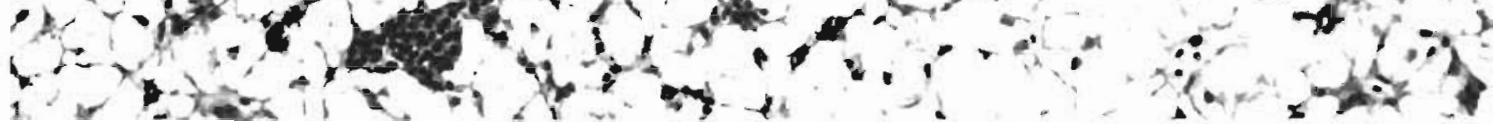

Fig. 1. Platichthys flesus luscus. Histological section of liver showing nests of lymphoid cells scattered throughout the hepatic parenchyma. Note marked (fatty) vacuolation of hepatocytes. H \& E, $\times 250$

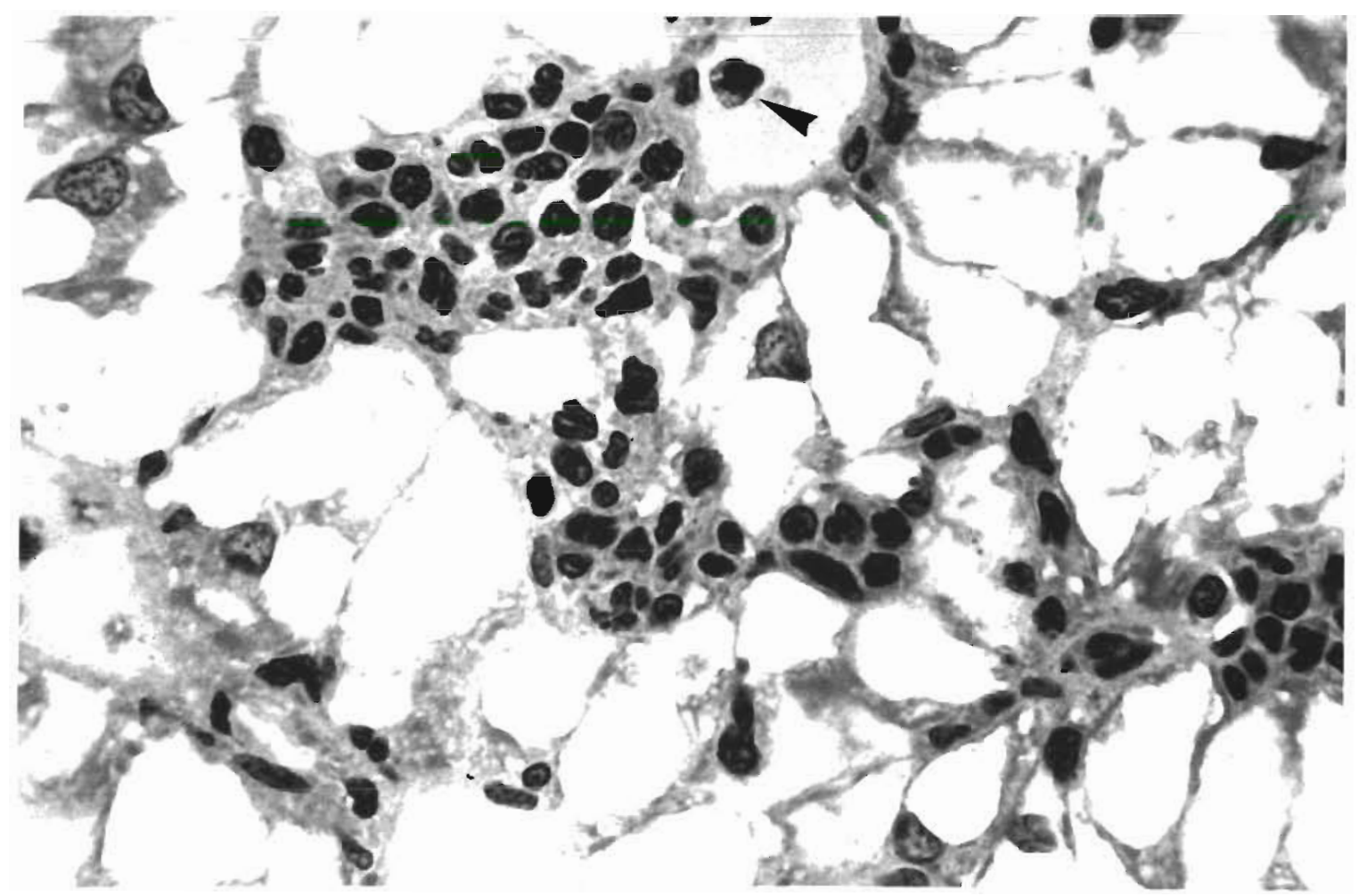

Fig. 2. Platichthys flesus luscus. Detail of lymphoid tumour cells in the liver. Cells exhibit lymphoid characteristics and one is present in a blood vessel (arrowhead). GMA section, $\mathrm{H} \& \mathrm{E}, \times 1000$ 


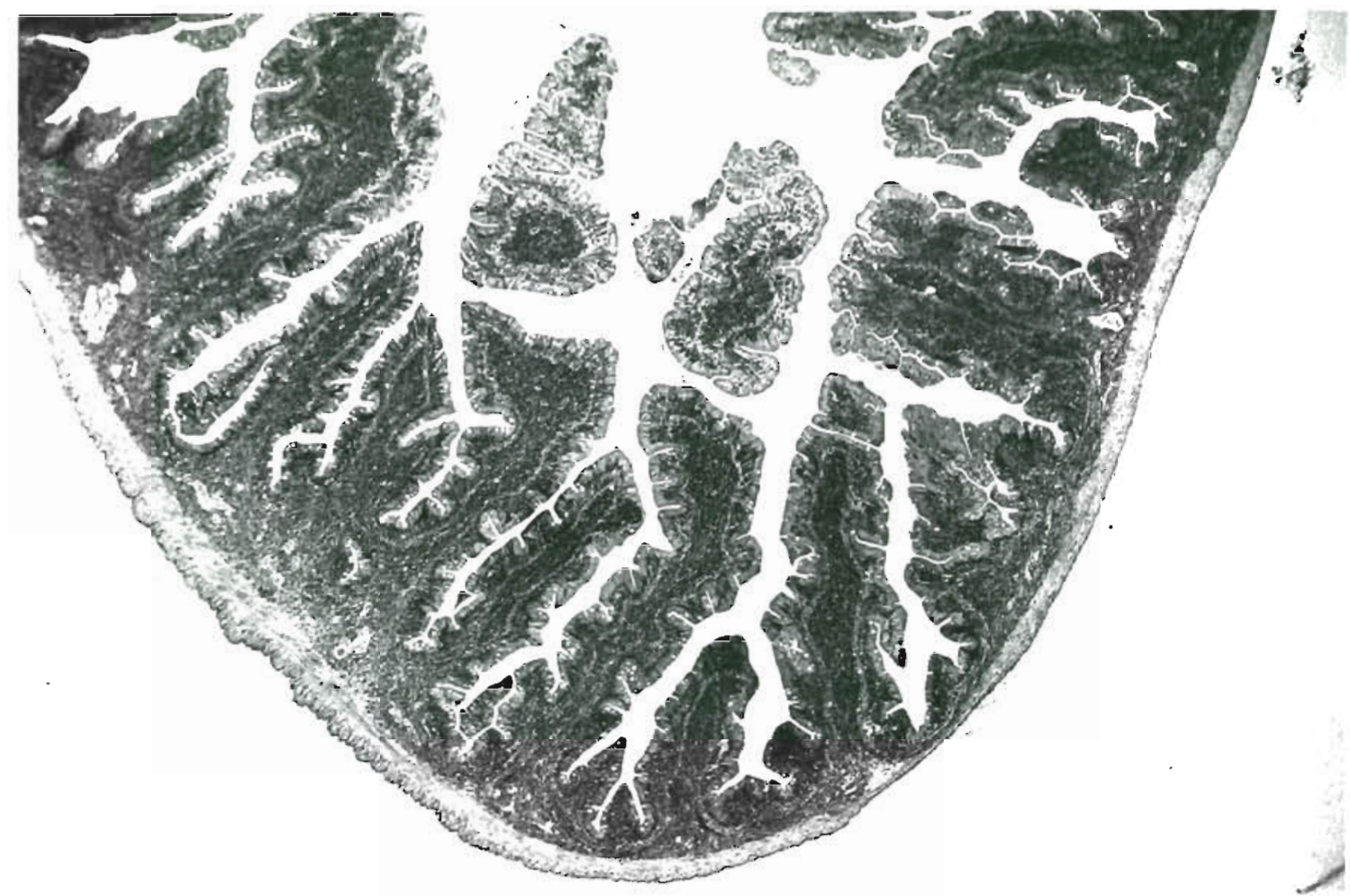

Fig. 3. Platichthys flesus Iuscus. Low-power view of intestine. Submucosa and propria are heavily infiltrated by lymphoid tumour cells. $H \& E, \times 40$

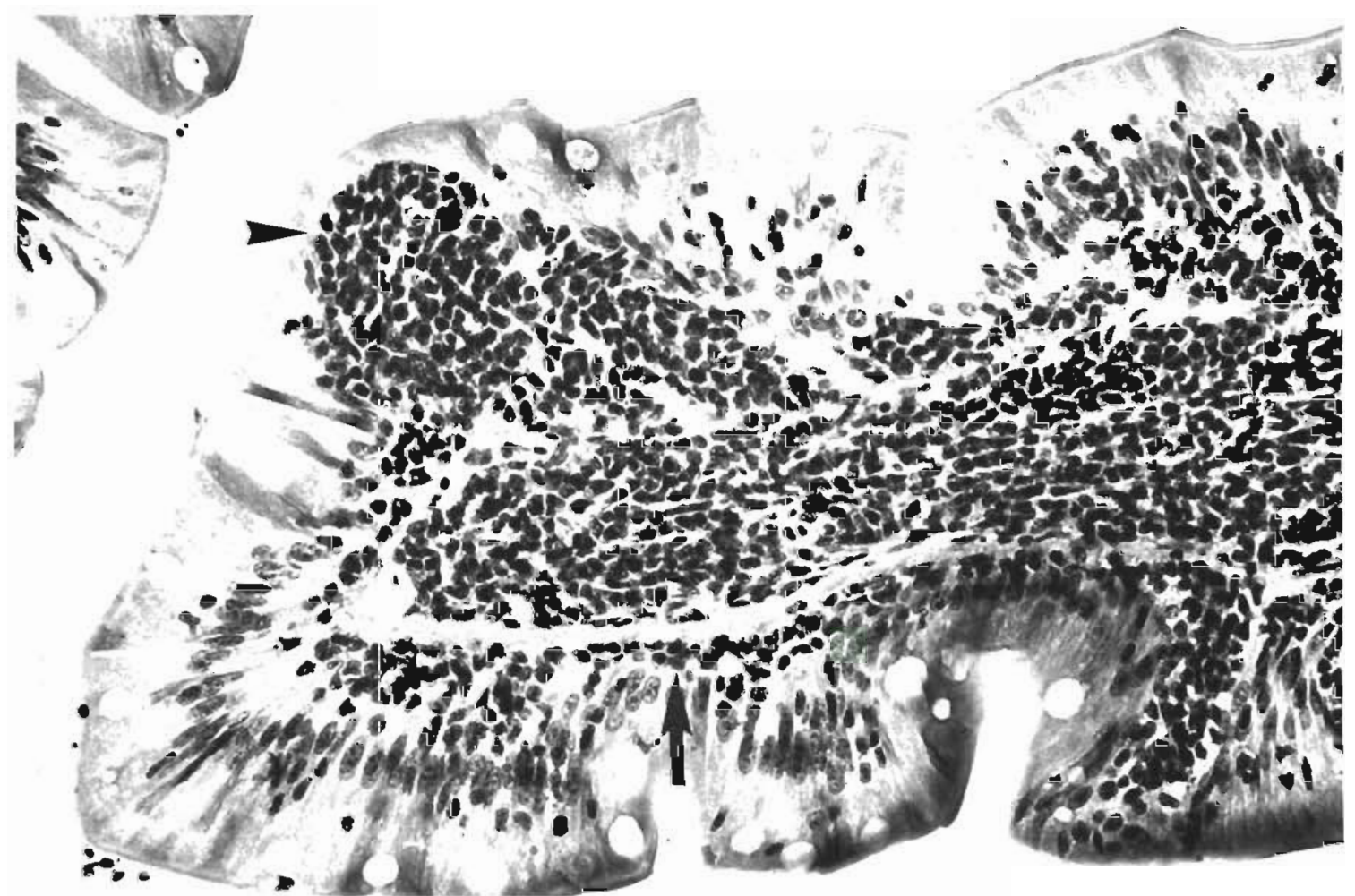

Fig. 4. Platichthys flesus luscus. Detail of an intestinal villus, exhibiting tumour cells in the propria as well as in the epithelial layer. The intra-epithelial tumour cells form a continuous sheet basally (arrow) as well as isolated nests (arrowhead). 
high level of differentiation: small uniform rounded cells with a moderate amount of cytoplasm and a small round to slightly irregular condensed nucleus. Mitotic figures were seen occasionally. There was no typical growth pattern nor was extracellular matrix being formed.

This condition was diagnosed as lymphatic leukaemia, based on cell characteristics and cell distribution. As there were no major gross lesions, the other lymphoid tissues were not sampled, and therefore the primary site of this tumour or its distribution in other organs could not be established.

Although the prevalence and etiology of lymphoid neoplasms in flounder are at present unknown, it seems important to communicate this case because of its possible relevance to future environmental monitoring programs. This specimen has been submitted to the Registry of tumors in lower animals, no. RTLA 4325.

Acknowledgements. The authors thank the skipper Roberto Perini and the crew of MS 'Bardia' who offered the opportunity to carry out the sampling, and Prof. Dr A. Angela Orio of the Faculty of Industrial Chemistry of the University of Venice for his support

Responsible Subject Editor: Professor N. Peters, Hamburg, F. R. Germany

\section{LITERATURE CITED}

Bowser, P. R. McCoy, C. P., MacMillan, J. R. (1985). A lymphoproliferative disorder in a channel catfish, (Ictalurus punctatus) (Rafinesque). J. Fish Dis. 8: 465-469

Donazzollo, R., Hieke Merlin, O., Menegazzo Vitturi, L., Orio A. A. (1983). Toxic elements in the Northern Adriatic Sea (the Italian area). Thalassia jugosl. 19: 111-119

Ferguson, H. W., Roberts, R. J. (1975). Myeloid leukosis associated with sporozoan infection in cultured turbot (Scophtalmus maximus). J. comp. Pathol. 85: 317-326

Harshbarger, J. C. (1989). Personal communication on behalf of the registry of tumors in lower animals (RTLA). Smithsonian Institution, Washington, DC

Mulcahy. F. M. (1980). The possible role of water pollutants in the aetiology of malignant lymphoma in the Northern Pike (Esox lucius L.). Rapp. P.-v. Réun. Cons. int. Explor. Mer. 179: $100-102$

Peters, N. (1.984). Diseases caused by neoplasia. In: Kinne, O. (ed.) Diseases of marine organisms, Vol. IV Part I, Introduction, Pisces. Biologische Anstalt Helgoland, Hamburg p. $418-419$

Schlumberger, H. G., Lucke, B. (1956). Tumors of fishes, amphibians, and reptiles. Cancer Res. 8: 657-754

Sfriso, A. Marcomini, A., Pavoni, B. (1987). Relationships between macroalgal biomass and nutrient concentrations in a hypertrophic area of the Venice Lagoon. Mar. enviror Res. 22: 297-312

Wellings, S. R. (1969). Neoplasia and primitive vertebrate phylogeny; echinoderms, prevertebrates, and fishes - a review. Nat. Cancer Inst. Monogr. 31: 59-128

Manuscript first received: August 1, 1989

Revised version accepted: October 26, 1989 